\title{
Neotectonic Evidences of Rejuvenation in Kaurik-Chango Fault Zone, Northwestern Himalaya
}

\author{
Moulishree Joshi $^{1}$, Girish Chandra Kothyari ${ }^{2}$, Arun Ahluvalia ${ }^{3}$, Pitambar Datta Pant ${ }^{1}$ \\ ${ }^{1}$ Department of Geology, Kumaun University, Nainital, Uttarakhand, India \\ ${ }^{2}$ Institute of Seismological Research, Gandhinagar, Gujarat, India \\ ${ }^{3}$ Centre for Advanced Studies in Geology, Panjab University, Chandigarh, India \\ E-mail: kothyarigirish_k@rediffmail.com,moulishreej@yahoo.com \\ Received April 28, 2010; revised May 30, 2010; accepted June 6, 2010
}

\begin{abstract}
Neotectonic investigations using morphotectonic parameters such as basin asymmetry, drainage anomalies, digital data interpretation and geomorphic field evidences were carried out in Satluj river valley downstream of Khab in the Kaurik Chango Fault (KCF) zone. The study reveals the presence of a north-south trending fault which is similar to the KCF. Unpaired, tilted terraces, V shaped valleys, deep gorges and lakes are the manifestations of fault movement in the area. Presence of deformation structures preserved in the palaeolake profile at Morang indicates that the area has also been seismically active in the past. In this paper we present a conceptual model of the formation of lakes in KCF zone. Morphometric analysis was carried out with the help of Digital Elevation Models (DEMs) and field investigations.
\end{abstract}

Keywords: Neotectonics, Kaurik Chango, Kinnaur, Satluj

\section{Introduction}

Himalayan mountain range was created as a result of the collision of the Indian and the Asian plate. Ensuing tectonic turmoil is witnessed in the form of intra-continental deformation along major faults and thrusts [1-4]. The Himalayan region is dissected by several NW-SE trending regional thrusts namely Indo Tsangpo Suture Zone, Main Central Thrust and Main Boundary Thrust. These thrust planes and their subsidiary fault systems are the foci of several devastating earthquakes. In the Satluj-Spiti river valleys, a number of N-S trending faults have disturbed the Precambrian-Palaeozoic succession of the Tethys Himalaya [5-8]. Kinnaur lies in the Higher Himalayan region between Main Central Thrust (MCT) and Indo-Tsangpo Suture Zone (ITSZ).

The expression of active tectonism in Kinnaur is reflected in tilted terraces, V shaped valleys, convex slopes, rampant landslides and gorges. Kinnaur is a seismically active segment of the Himalaya. A major earthquake of magnitude $>6.8$ occurred in this region in 1975 [9]. The region exhibits diverse deformation including strike-slip, normal and thrust faulting [10]. Kaurik-Chango fault has been studied in detail by several workers [9-13]. Several palaeolake profiles have been reported along the Kaurik
Chango fault in the upper Spiti valley [10,12-15]. However, research has not been done in the area between Khab and Akpa. This paper is an attempt to study the neotectonic activity in the area using morphotectonic parameters. The study area lies between $78^{\circ} 00^{\prime}$ and $79^{\circ} 00^{\prime} \mathrm{E}$ and $31^{\circ} 25^{\prime}$ to $32^{\circ} \mathrm{N}$ in the rugged Higher Himalayan terrain characterized by barren slopes and steep gradient.

\section{Geology of the Area}

Satluj River has been studied in detail by a number of workers [7,16-19]. The study area comprises thick succession of medium to high grade metamorphic rocks and their sedimentary cover. The succession is emplaced by granite intrusions of varying ages. Rocks of Vaikrita and Haimanta Groups are exposed in the region Figure 1(a). Vaikrita Group comprises psammatic gneiss with quartzite bands, banded gneiss, granite gneiss, quartz mica gneiss. Haimanta Group comprises grey-purple quartzites, black carbonaceous phyllites and quartz mica schist interbedded with amphibolites and calc schists [19].

Figure 1(b) shows the SRTM image of the study area. River Spiti takes an abrupt southerly turn and flows parallel to the Kaurik-Chango fault near Sumdo. Seven terraces have been observed on the eastern bank [19]. There 
is no evidence of terraces on the western bank. This may be due to the shifting of the river westward owing to the uplifted eastern block of the Kaurik Chango fault [20]. Quaternary fluvio-lacustrine deposits occur all along the Satluj valley downstream of Khab. These deposits are well preserved on the eastern bank. Several evidences gathered during the present work between Khab and Akpa indicate that Kaurik-Chango fault extends downward upto Akpa showing an uplifted eastern block. There are indications of tectonic and seismic activity similar to those in the Spiti valley.

In this paper, several morphotectonic indices were used to analyze the tectonic deformation in the area. Digital Elevation Model and satellite data were used to study the landscape evolution of the region. Field investigations were carried out to verify the data generated in the lab.

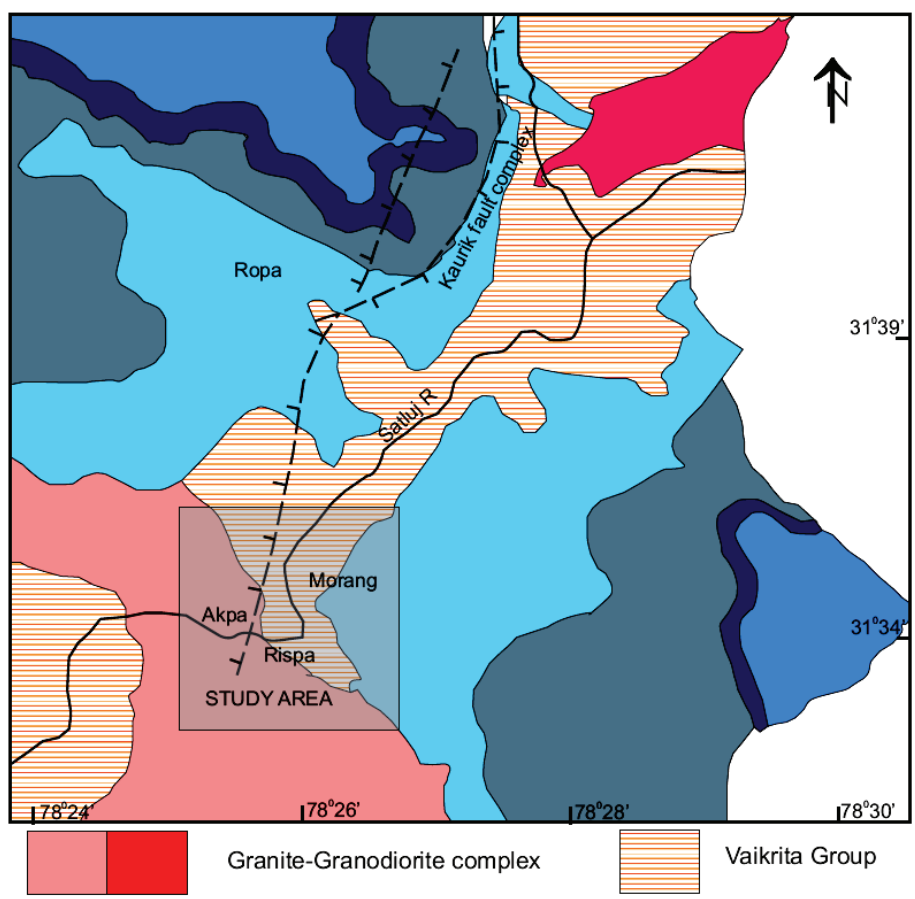

Carbonates of Eocambrian Palaeozoic (Haimanta)

(a)

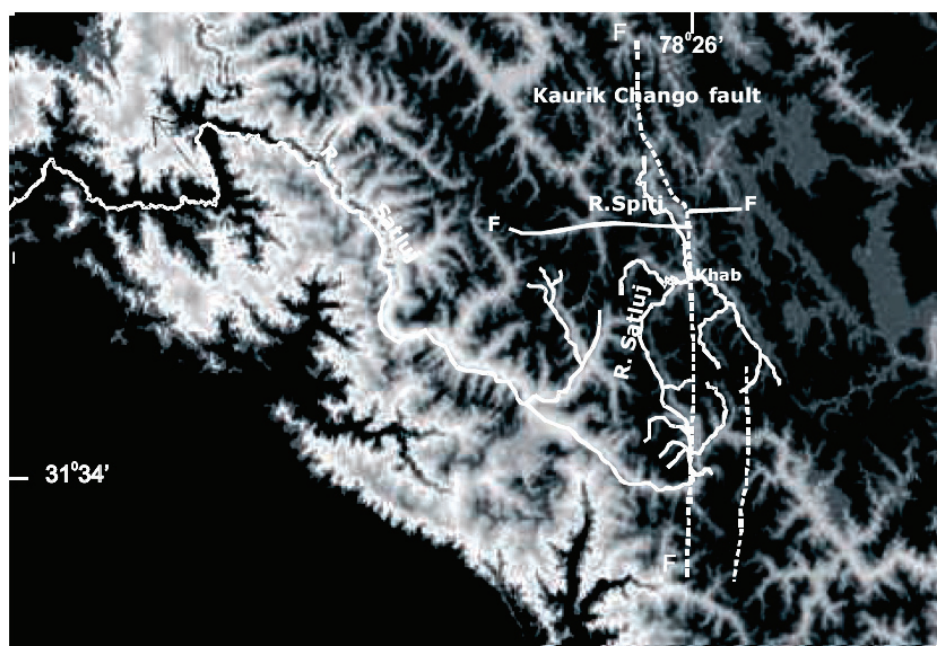

(b)

Figure 1. (a) Geological map of the study area (after Bhargava and Bassi, 1998); (b) SRTM image of Himachal Himalaya showing the location of the study areas. Also marked are the major drainage, thrusts and faults in the study area (image taken from NASA-SRTM program). 


\section{Methodology}

Digital data interpretation was carried out with the help of a 3D Digital Elevation Model (DEM) and 2D topographic map to the scale 1:50,000. The softwares that were used to process the digital data are Surfer 9.6 and Globe Mapper. The Digital Elevation Model (DEM) Figure 2(a) of the area indicates significant changes in the topography and development of geomorphic features such as fault facets, abruptly changing river course, meandering and widening of the river, formation of terraces, vertical down cutting and formation of gorges. The uplifted eastern block can be seen clearly in the model. SRTM data of the study area was downloaded from the site (http: //srtm.csi.cgiar.org.). Basin asymmetry was calculated with the help of the SRTM data Figure 2(b). Asymmetry factor $\mathrm{AF}$ is defined as $\mathrm{AF}=100$ (Ar/At) where $\mathrm{Ar}$ is the area of the basin to the right (facing downstream)

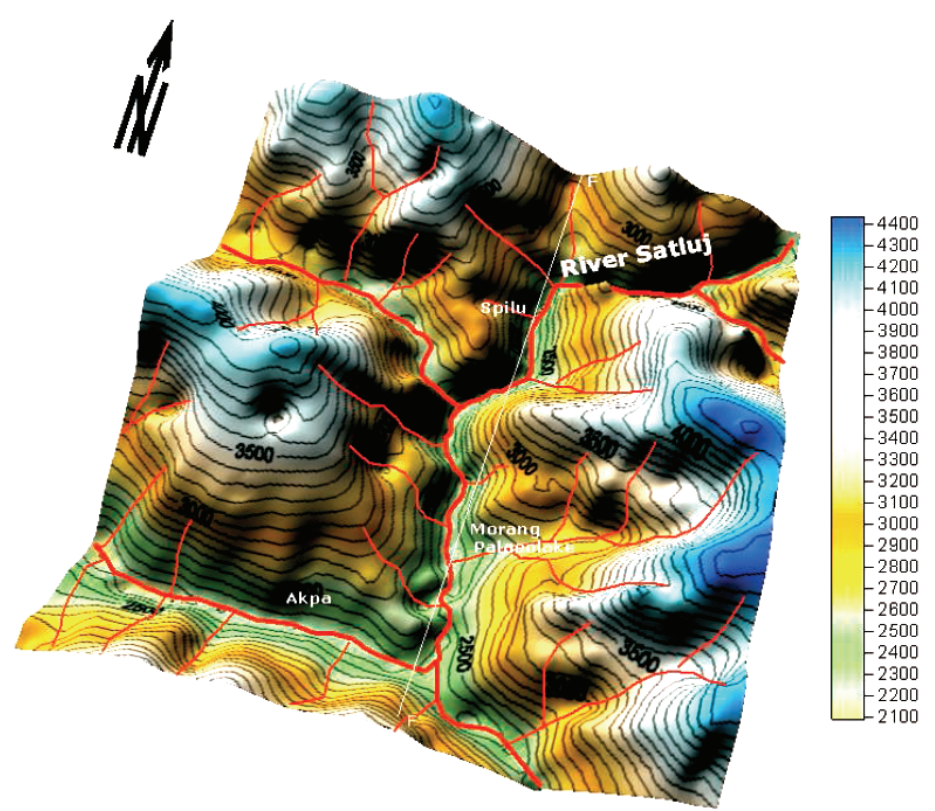

(a)

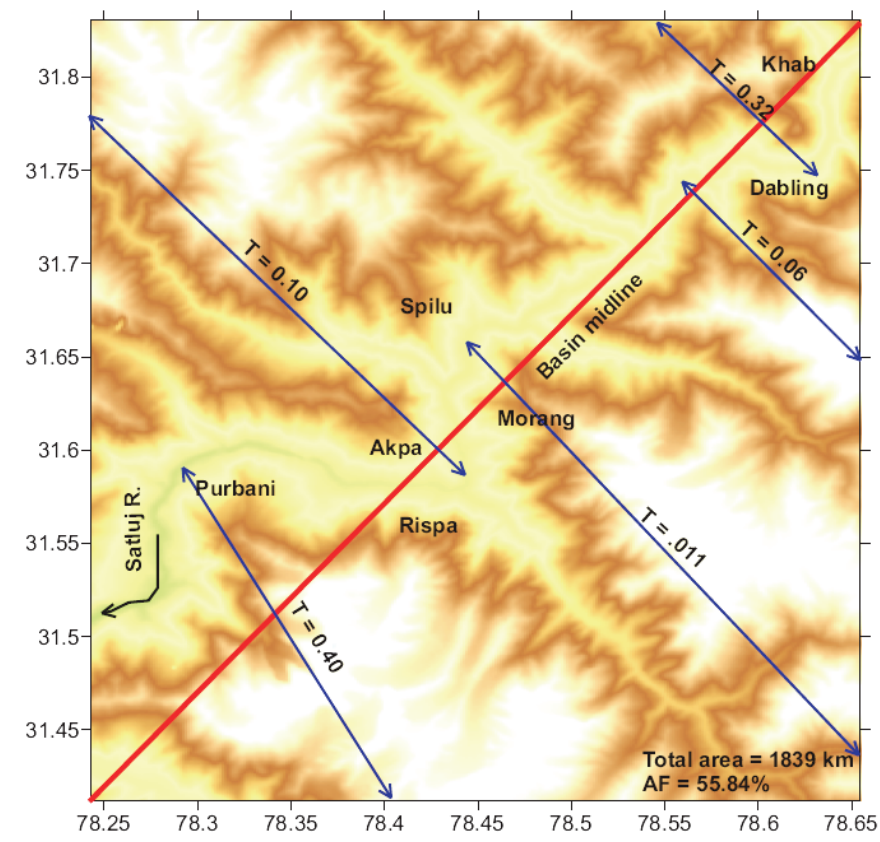

(b)

Figure 2. (a) Digital elevation model of the study area; (b) SRTM image of the study area showing basin asymmetry. 
of the trunk stream and At is the total area of the drainage basin. In case of tectonic tilting, the value of AF becomes greater than 50 and the tributaries present on the tilted side of the main stream grow longer than those on the other side [21]. Transverse topographic symmetry factor $(\mathrm{T})$ is defined as $\mathrm{T}=\mathrm{Da} / \mathrm{Dd}$ where $\mathrm{Da}$ is the distance from midline of the drainage basin to the midline of the active meander belt. Dd is the distance from the basin midline to basin divide. Value of $\mathrm{T}$ ranges between 0 to $1 . \mathrm{T}=0$ implies a perfectly symmetrical basin and $\mathrm{T}$ $=1$, a perfectly asymmetrical one [20,21].

The landscape morphology of an area is governed by drainage of the rivers and their tributaries. Tectonic deformation has a direct impact on the drainage of that area. Tectonic deformation changes the channel slope which is responsible for variation in the channel morphology [22-27].

Drainage map and stream profiles were prepared with the help of the SRTM data. Valley incision is used to define relative uplift [24,28]. Cross valley profile for the Satluj basin was prepared with the help of SRTM data. A high valley-floor-width to valley-height ratio (seen in a broad valley) indicates tectonic stability. On the other hand, a low valley-floor-width to valley-height ratio (seen in a narrow valley) is associated with recent tectonic movement [29]. Asymmetry Factor calculated for the Satluj river basin is 55.84 indicating that the basin is asymmetrical. Transverse Topographic symmetry factor $(\mathrm{T})$ calculated for the basin is given in Table 1. The data clearly shows that the basin is tilted towards the northwest Figure 2(b).

\section{Drainage and Stream Profiles}

Drainage map of the area shows lower order streams joining the trunk stream at $90^{\circ}$. The streams on the eastern block are longer and more in number compared to those on the western block. River Satluj flows through a crystalline basement belonging to Vaikrita Group. The area lies in the Kaurik-Chango fault zone. Quaternary reacti- vation of these faults has lead to bedrock incision by Satluj which flows in a gorge for most of its course in the study area Figure 3(a). Longitudinal profile of Satluj shows a change in elevation near Spilu. Between Spilu and Akpa, the river has carved a deep gorge. This abrupt change in river morphology indicates that the river course in this region is tectonically controlled Figures 3(b) - (c). Low valley floor width to height ratio suggests that the river is cutting downwards due to the tectonic activity in the region.

\section{Geomorphology}

The Satluj river basin under investigation is a rectangular basin with an area of $1839 \mathrm{sq} \mathrm{km}$. The mean height of the basin is $3118.3 \mathrm{~m}$. River Satluj is a $4^{\text {th }}$ order stream as per the Horton-Strahler method of stream ordering. The highest point in the basin is about $4400 \mathrm{~m}$. The total basin relief is $2400 \mathrm{~m}$. The streams on the eastern block flow in escarpments along most of their course. Landslide cones and springs are rampant on the eastern block Figure 3(e). The river flows in a narrow valley for most of its stretch from Spilu to Morang Figure 4(a).

River Satluj has carved three levels of unpaired terraces at Akpa Figure 4(b). The river in this region deflects abruptly towards the west. Tectonic rejuvenation of the N-S fault has also caused the tilting of the terraces Figure 4(c). Landslide cones and springs are rampant along the N-S lineament Figure 4(d).

In Morang, fluvio-lacustrine deposits are exposed for about $1 \mathrm{~km}$ Figure 4(e). These deposits are 60-70 m thick. The sedimentary succession is represented by laminated clay-silty clay and horizontally bedded sands. Laminated sediments dominate the lake section. Presence of lacustrine deposits also suggests that neotectonic movements along the N-S fault were responsible for blocking the river and forming a lake. The uplifted eastern block led to the damming of the rivulet, Khokpa nala. Ensuing landslides facilitated the formation of a lake on the footwall

Table 1. Morphometric characters of Satluj river showing active nature.

\begin{tabular}{lcccc}
\hline $\begin{array}{l}\text { River } \\
\text { Basin }\end{array}$ & $\begin{array}{c}\text { Basin Area } \\
\text { Total }\left(\mathrm{Km}^{2}\right)\end{array}$ & $\begin{array}{c}\text { Basin } \\
\text { Asymmetry (AF) }\end{array}$ & $\begin{array}{c}\text { Topographic symmetry } \\
\text { factor (T) }\end{array}$ & $\begin{array}{c}\text { Valley Floor width } \\
\text { Ratio (Vf) }\end{array}$ \\
\hline & & 0.32 & 1.2 \\
Height \\
Satluj
\end{tabular}




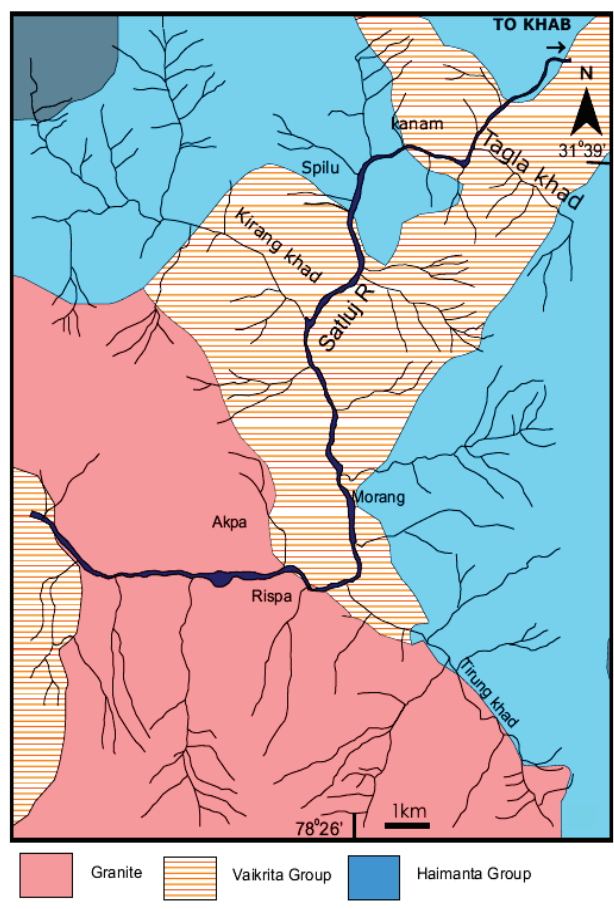

(a)

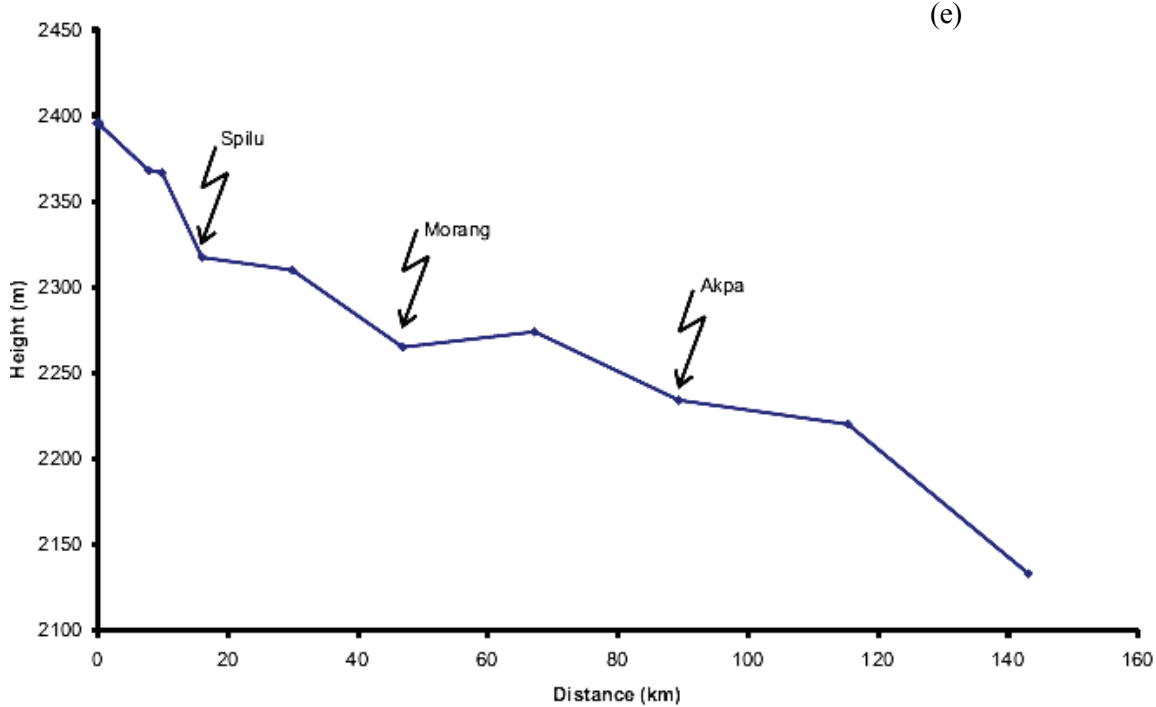

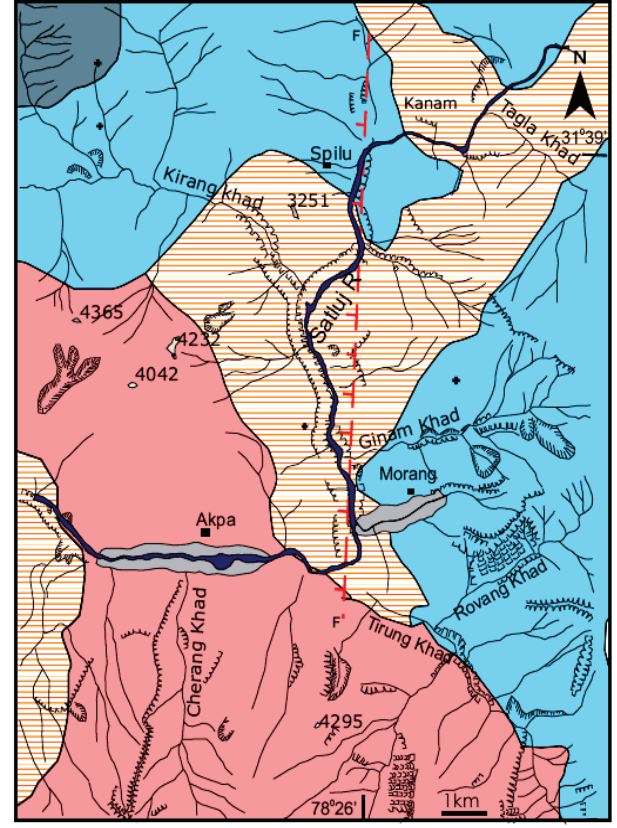

$\square \sqrt{ }$ Escarpments $\square$ Streams $\square$ Fluvio-Lacustrine deposits + Springs $\geqslant$ Landsildes

(e)

(b)

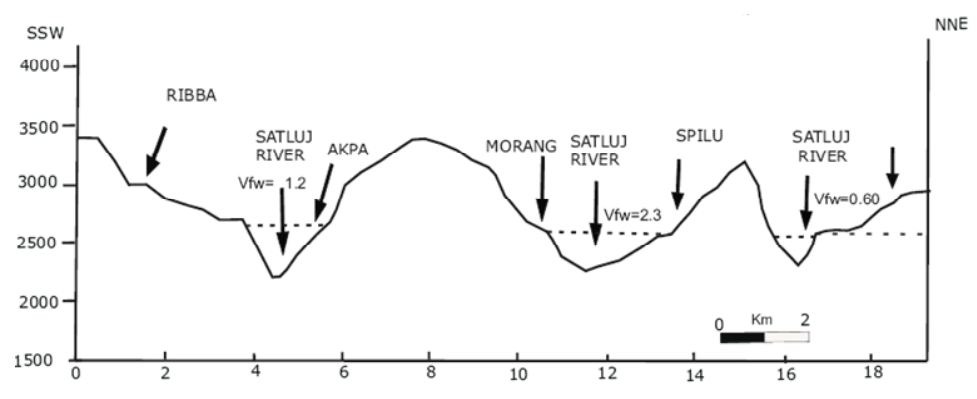

(c)

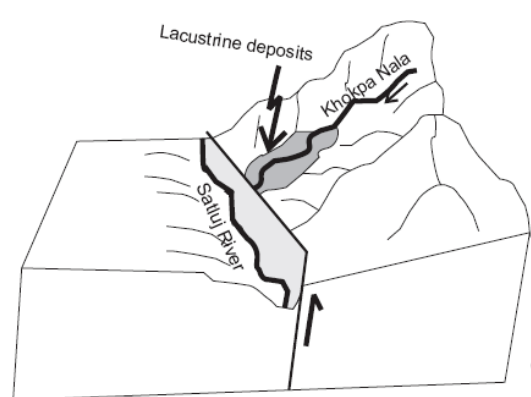

(d)

Figure 3. (a) Drainage map of the study area; (b) longitudinal profile of river Satluj in the study area; (c) cross valley profile of river Satluj in the study area; (d) hypothetical model showing lake formation in KCF zone; (e) geomorphological map of the study area. 


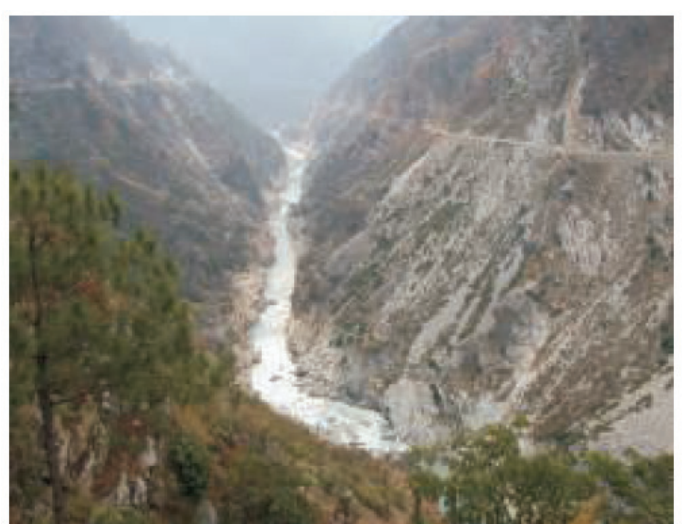

(a)

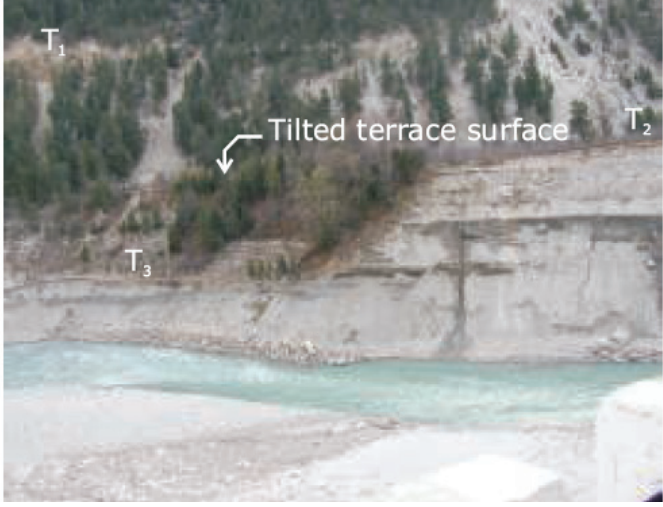

(c)

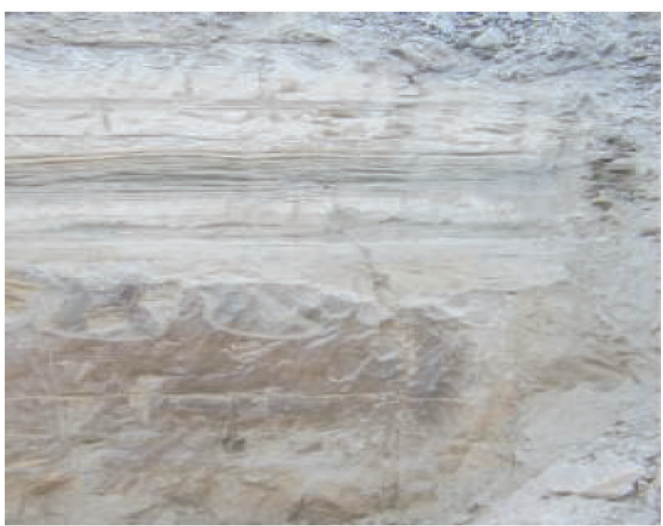

(e)

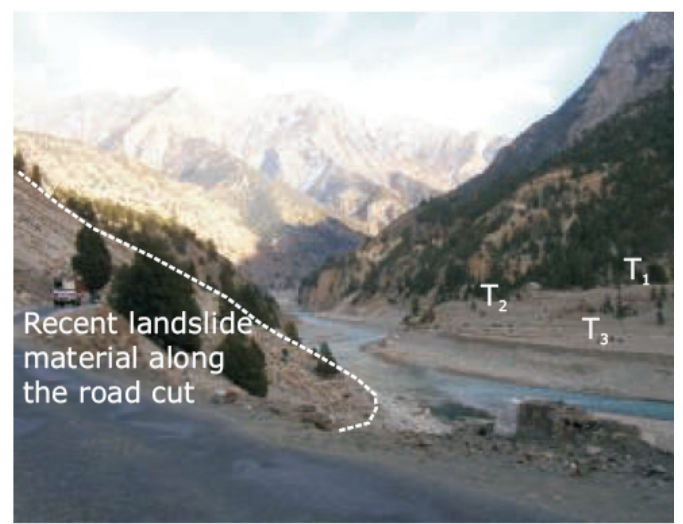

(b)

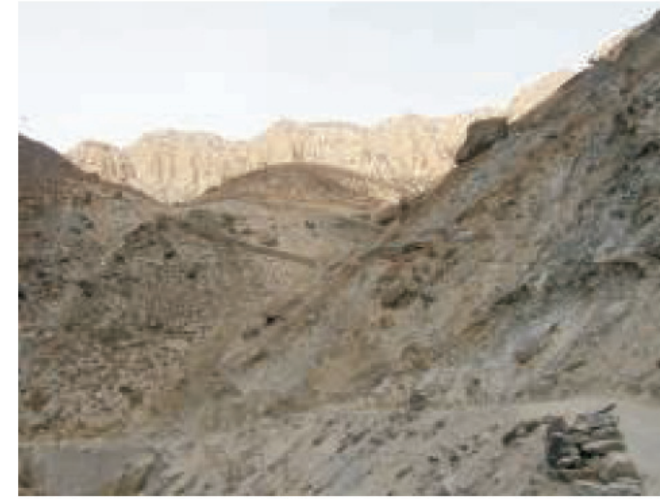

(d)

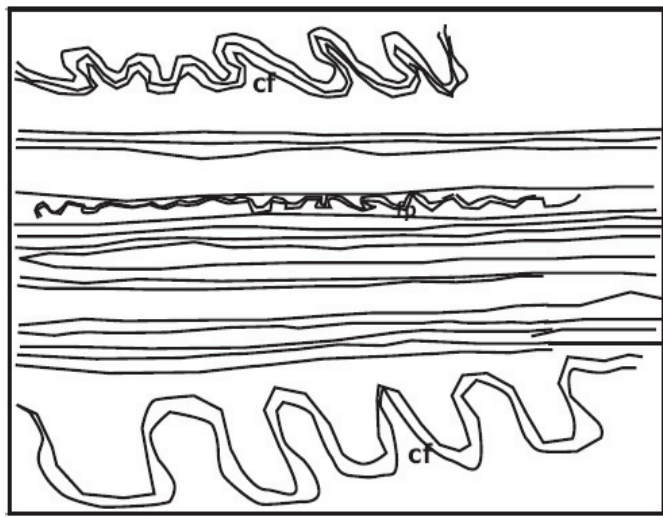

(f)

Figure 4. (a) River Satluj flowing in a narrow valley from Spilu to Morang; (b)-(c) three levels of unpaired terraces formed by the river at Akpa, showing tilted surface; (d) recent landslide material; (e) fluvio lacustrine deposits at Morang; (f) sketch of deformation structure in the lacustrine profile.

block Figure 3(d). At least five levels of deformation structures are exposed in the palaeolake profile at Morang Figure 4(f).

\section{Discussion}

Kinnaur and Lahaul Spiti districts of Himachal Pradesh were severely rocked by a major earthquake of magnit- ude $>6.8$ in 1975. The earthquake was associated with movements along a subvertical N-S trending normal fault named Kaurik-Chango fault. Luminescence chronology of seismites in Sumdo suggests that activation of Kaurik-Chango fault and seismic activity dates back to Late Pleistocene [15].

In the present area of investigation, a N-S lineament was observed along which river Satluj flows for a consi- 
derable distance before getting deflected near Akpa. A number of neotectonic evidences which were gathered during the study testify to its active nature. Morphotectonic parameters such as Asymmetry Factor (AF) and Transverse topographic symmetry factor (T) as well as the field evidences suggest that the Satluj river basin is tilted. DEM of the area also shows the difference in elevation of the two blocks. Drainage analysis clearly displays the effect of tectonic rejuvenation. Blocking of Khokpa nala, a small rivulet took place due to fault movement leading to the formation of Morang palaeolake on the eastern block. Several levels of deformation structures have been observed in the fluvio-lacustrine profile at Morang. Similar structures are seen near Kaurik Chango fault in Sumdo and Leo. Presence of deformation structures in the Morang fluvio-lacustrine profile indicate that the area lies in the tectonically and seismically active zone and has experienced several pulses of intense seismic activity. Neotectonic indicators such as the uplifted terrain, unpaired terraces, fluvio-lacustrine deposits, deformation structures, alignment of springs and landslides in the fault zone are strong evidences of the active nature of the N-S fault in the study area.

\section{Acknowledgements}

The first and second authors are grateful to CSIR, New Delhi for providing financial support in the form of Research Associateship (9/428 (57) 2004-EMR-I) and Senior Research Fellowship (9.429(61)2K6-EMR1). Department of Geology, Kumaun University Nainital is acknowledged for providing facilities.

\section{References}

[1] A. Gansser, "The Geology of Himalaya," Wily Interscience, London, 1964, p. 289.

[2] T. Nakata, "Geomorphic History and Crustal Movements of the Himalayas," Institute of Geography Tohoku University, Sendai, 1972, p. 77.

[3] T. Nakata, O. Kenshiro and S. H. Khan, "Active Faults, Stress Field and Plate Motion along the Indo-Eurasian Plate Boundary," Tectonophysics, Vol. 181, No. 1-4, 1990, pp. 83-95.

[4] J. C. Atchinson, J. R. Ali and A. M. Davis, "When and Where did India and Asia Collide?" Journal of Geophysical Research, Vol. 112, 2007, pp. 1-19.

[5] H. H. Hayden, "The Geology of Spiti with Parts of Bushahr and Rupshu," Geological Survey of India Memoir, Vol. 6, 1904, pp. 1-121.

[6] V. J. Gupta and N. S. Virdi, "Geological Aspects of Kinnaur Earthquake, Himachal Pradesh," Journal of Geological Society India, Vol. 16, No. 4, 1975, pp. 512-514.

[7] O. N. Bhargava and U. K. Bassi, "Geology of Spiti-Kinnaur Himachal Himalaya," Memoir Geological Survey of
India, Vol. 124, 1998, p. 212.

[8] O. N. Bhargava, R. N. Srivastava and S. K. Gadhoke, "The Proterozoic-Palaeozoic Spiti Sedimentary Basin," In: S. K. Tandon, C. Pant and S. M. Casshyon, Eds., Sedimentary Basins of India: Tectonic Context, Gyanodaya Prakashan, Nainital, 1991, pp. 236-260.

[9] K. N. Khattri, K. Rai, A. K. Jain, H. Sinvhal, V. K. Gaur and R. S. Mithal, "The Kinnaur Earthquake, Himachal Pradesh, India of $19^{\text {th }}$ January 1975," Tectonophysics, Vol. 49, No. 1-2, 1978, pp. 1-21.

[10] S. Singh and A. K. Jain "Paleosiesmicity: Geological Evidences along the Kaurik-Chango Fault Zone and Other Related Areas in Lahaul-Spiti and Ladakh Himalaya," In: O. P. Varma, Ed., Highlights in Earth Sciences DST's Spl. Vol. 2 on Seismicity, International Geological Congress, 2001, pp. 205-225.

[11] O. N. Bhargava, S. S. Ameta, R. K. Gaur, S. Kumar, A. N. Agarawal, P. M. Jalote and M. L. Sadhu, "The Kinnaur (H.P., India) Earthquake of 19 January, 1975: Summary of Geoseismological Observations," Bulletin of the Indian Geological Association, Vol. 11, No. 1, 1978, pp. 39-53.

[12] T. N. Bagati, "Lithostratigraphy and Facies Variation in the Spiti Basin (Tethys), Himachal Pradesh," Journal of Himalayan Geology, Vol. 1, No. 1, 1990, pp. 35-47.

[13] A. K Jain and S. Singh, "Palaeoearthquakes along the Kaurik-Chango Fault Zone, Satluj-Spiti Valleys, Himachal Pradesh, India: Geological Evidence. Extended Abstract of Indo-US Workshop on Palaeoseismicity," WIHG, Dehradun, 1997, pp. 62-67.

[14] R. Mohindra and T. N. Bagati "Seismically Induced Soft Sediment Deformation Structures (Seismites) around Sumdo in the Lower Spiti Valley (Tethys Himalaya)," Sedimentary Geology, Vol. 101, No. 1, 1996, pp. 69-83.

[15] D. Banerjee, A. K. Singhvi, T. N. Bagati and R. Mohindra, "Luminescence Chronology of Seismites at Sumdo (Spiti Valley) Near Kaurik-Chango Fault, Northwestern Himalaya," Current Science, Vol. 73, No. 3, 1997, pp. 276-281.

[16] V. P. Sharma, "Geology of the Kullu-Rampur Belt, Himachal Pradesh," Memoir Geological Survey of India, Vol. 106, No. 2, 1976, pp. 235-403.

[17] A. P. Tiwari, R. K. Gaur and S. S. A. Ameta, "Note on the Geology of a Part of Kinnaur District, Himachal Pradesh. Him," Geology, Vol. 8, No. 1, 1978, pp. 574 582.

[18] U. K. Bassi and S. A. Chopra, "Contribution to the Geology of Kinnaur Himalaya, Himachal Pradesh," International Journal of Earth Sciences, Vol. 10, No. 1, 1983, pp. 96-99.

[19] S Srikantia and O. N. Bhargava, "Geology of Himachal Pradesh," Geological Society of India, 1998, p. 406.

[20] S. S. Ameta, "Some Observations on Geomorphology of Spiti Valley, Lahaul and Spiti distt. Himachal Pradesh," Himalayan Geology, Vol. 9, No. 2, 1997, pp. 646-656.

[21] C. A. Keller and N. Pinter, "Active Tectonics: Earthquake, Uplift and Landscape," Prentice Hall, New Jersey, 1996, p. 338. 
[22] N. S. Virdi, G. Philip and S. Bhattacharya, "Neotectonic Activity in the Markanda and Bata River Basins, Himachal Pradesh, NW Himalaya: A morphotectonic Approach," International Journal of Remote Sensing, Vol. 27, No. 10, 2006, pp. 2093-2099.

[23] A. W. Burnett and S. A. Schumm, "Alluvial River Response to Teotectonic Deformation in Louisiana and Mississippi," Science, Vol. 222, No. 4619, 1983, pp. 49-50.

[24] S. Ouchi, "Response of Alluvial Rivers to Slow Active Tectonic Movement," Geological Society of America Bulletin, Vol. 96, No. 4, 1985, pp. 504- 515.

[25] D. I. Gregory and S. A. Schumm, "The Effect of Active Tectonics on Alluvial River Morphology," In: K. S. Richards, Ed., River Channels: Environment and Process, Blackwells, London, 1987, pp. 41-68.

[26] S. A. Schumm, J. F. Dumont and J. M. Holbrook, “Active
Tectonics and Alluvial Rivers," Cambridge University Press, New York, 2000, p. 276.

[27] V. Jain and R. Shina, "Response of Active Tectonics on the Alluvial Bagmati River, Himalayan Foreland Basin, Eastern India," Geomorphology, Vol. 70, 2005, pp. 339356.

[28] W. B. Bull and L. D. Mc. Fadden, "Tectonic Geomorphology North and South of Garlock Fault California," In: D. O. Doehring, Ed., Geomorpholoy in Arid Regions, Proceedings of $8^{\text {th }}$ Annual Geomorphology Symposium, University of New York, Binghampton, 1977, pp. 115137.

[29] L. Mayer, "Tectonic Geomorphology of Escarpments and Mountain Fronts," In: R. E. Wallace, Ed., Active Tectonics, National Research Council, Washington, D.C., 1985, pp. $125-135$ 